\title{
$3,4,5,6$-テトラクロロフルオレスセイン水銀化合物を用いる チオ尿素あるいは塩化セチルピリジニウムのけい光光度定量*
}

森逸男**

(1973 年 11 月 10 日受理)

\begin{abstract}
3, 4, 5, 6-テトラクロロフルオレスセインテトラフセトオキシ水銀化合物 $\left(3,4,5,6\right.$-T. Cl. Fl. $\left.\mathrm{Hg}_{4}\right)$ は チオ尿素あるいは塩化セチルピリジニウム (CPG) などと反応して赤色呈色体を生成するとともに, 3, 4, 5, 6-T.Cl.Fl. $\mathrm{Hg}_{4}$ 液のけい光を減少させるので，新たに 3, 4, 5, 6-T.Cl.Fl. $\mathrm{Hg}_{4}$ を用いるチオ尿 素，あるいは CPG のけい光光度定量法について検討した. その結果 $\mathrm{pH} 8.9$ でチオ尿素に $1.0 \times$ 10-4M 3,4,5,6-T.Cl.Fl. $\mathrm{Hg}_{4}$ を加えて得た呈色体，あるいは $\mathrm{pH} 6.95$ で CPC に $1.0 \%$ ボリビニ ルビロリドン (PVP) 液 $1.0 \mathrm{ml}$ および $1.25 \times 10^{-5} M 3,4,5,6-\mathrm{T} . \mathrm{Cl} . \mathrm{Fl} . \mathrm{Hg}_{4}$ を加えて得た呈色体の $555 \mathrm{~nm}$ におけるけい光を，水銀ランプを光源として $365 \mathrm{~nm}$ の励起波長を用いて測定することにより $0 \sim 19.5 \mu \mathrm{g} / 10 \mathrm{ml}$ チオ尿素あるいは $0.15 \sim 1.0 \mu \mathrm{g} / 10 \mathrm{ml}$ CPC を感度よくけい光光度定量することが できた。
\end{abstract}

\section{1 緒言}

最近，フルオレスセイン水銀化合物 $\left(\mathrm{Fl} . \mathrm{Hg}_{4}\right)$ を用い

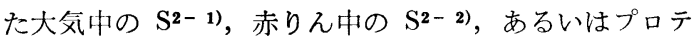
イン，プリンなどの分析法34) などについて報告されて いる. 著者は $\mathrm{Fl} \cdot \mathrm{Hg}_{4}$ にまさる試莧の合成とその利用を 目的として新たに $2^{\prime}, 4^{\prime}$-ジクロロフルオレスセイン5)の 水銀化合物 $\left(2^{\prime}, 4^{\prime}-\mathrm{D} . \mathrm{Cl}\right.$. Fl. $\left.\mathrm{Hg}_{2}\right), 2^{\prime}, 7^{\prime}-$-シクロロフル オレスセイン゙）の水銀化合物 $\left(2^{\prime}, 7^{\prime}-\mathrm{D} . \mathrm{Cl}\right.$.Fl. $\left.\mathrm{Hg}_{2}\right)$ な らびに 3,4,5,6-テトラクロロフルオレスセインの水銀 化合物（3, 4, 5, 6-T.Cl.Fl. $\left.\mathrm{Hg}_{4}\right)$ を合成してチ才尿素あ るいは陽イオン性界面活性剂の塩化セチルピリジウム (CPC)への利用を検討した. その結果， 3, 4, 5, 6-T.Cl. Fl.Hg ををオオ尿素，あるいは CPC などに用いた場合 最も鮮明な呈色体を生成するとともに， 3, 4, 5, 6-T.Cl. $\mathrm{Fl} . \mathrm{Hg}_{4}$ 液とそのチ才尿素, あるいは $\mathrm{CPC}$ 液とのけい 光強度の差が大で， $0 \sim 19.5 \mu \mathrm{g} / 10 \mathrm{ml}$ チ才尿素，ある いは $0.15 \sim 1.0 \mu \mathrm{g} / 10 \mathrm{ml} \mathrm{CPC}$ のけい光光度定量に利 用できることを認めた。

* 八イドロオキシフルオランおよびその誘導体の有機 試薬としての利用研究 (第 15 報). 前報は森 逸 男 : 薬誌，92，246（1972）

** 大阪薬科大学 : 大阪府松原市河合 2-10-65

\section{2 試薬および装置}

\section{1 試 薬}

$\mathrm{Fl}$ 誘導体の水銀化合物溶液 : $\mathrm{Fl}\left(\mathrm{HgOCOCH}_{3}\right)_{4} 171.0$ $\mathrm{mg}, \quad 3,4,5,6-\mathrm{T} . \mathrm{Cl} . \mathrm{Fl}(\mathrm{HgOCOCH})_{4}, 188.1 \mathrm{mg}, 2$, 4'-D. Cl. Fl $\left(\mathrm{HgOCOCH}_{3}\right)_{2}$ お よび 2', 7'-D. Cl. Fl $(\mathrm{HgO}$ $\left.\mathrm{COCH}_{3}\right)_{2} 114.8 \mathrm{mg}$ を $1 N$ 水酸化ナトリウム $1.0 \mathrm{ml}$ に溶解したのち，水を加えて全量 $250 \mathrm{ml}$ の $5.0 \times 10^{-4}$ $M$ 液として用いた。

チオ尿素誘導体の溶液：チオ尿素，ジトリルチオ尿 素, ジフェニルチオ尿素, フェニルチオ尿素, チオフセ トアミド，チオセミカルバジドなどの $5.0 \times 10^{-4} M$ 水 溶液またはメタノール液を調製して用いた。

CPC 溶液 $: 1.0 \times 10^{-2} M$ CPG の $20 \%$ メタノール液 より適宜水を加えて $5 \times 10^{-4} M$ 液として用いた.

Grote 試液67)： ニトロプルシドナトリウム $0.5 \mathrm{~g}$ と 塩酸ヒドロキシルアミン $0.5 \mathrm{~g}$ を水 $10 \mathrm{~m} l$ に溶解後, 炭酸水素ナトリウム $1.0 \mathrm{~g}$ と臭素水 2 滴を加光, 水を加 えて全量 $25.0 \mathrm{~m} l$ とする.

ポリビニルピロリドン (PVP) 溶夜 : $\mathrm{PVP}(\mathrm{K}=30)$ の $1.0 \%$ 水溶液を調製して用いた.

䌅衝溶液：Sörensen のほう砂一水酸化ナトリウム液 （pH 8.9）および，ほう砂一塩酸液（pH 6.95）を調製 して用いた。

なお，試薬はすべて特級品を用い，水は再蒸留水を用 いた. 


\section{$2 \cdot 2$ 装}

けい光スペクトルおよびけい光の測定 : けい光スペク トルの測定には日立 MPF-2A 型分光けい光光度計で光 源にキセノンランプを，またけい光の測定には日立 203 型分光けい光光度計で光源に水銀ランプを用い，それぞ れ層長 $10 \mathrm{~mm}$ の石英製セルを用いた。

$\mathrm{pH}$ の測定：日立堀場 M5 型および東亜電波 HM5A

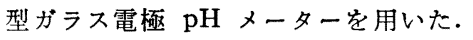

\section{3 定量操作}

\section{1 チオ尿共}

$19.5 \mu \mathrm{g}$ 以下のチオ尿素の溶液に緩衝液（ $\mathrm{pH} 8.9 ）$ $2.0 \mathrm{ml}, 5.0 \times 10^{-4} M 3,4,5,6-\mathrm{T} . \mathrm{Cl} . \mathrm{Fl} . \mathrm{Hg}_{4}$ 液 $2.0 \mathrm{ml}$ を加え, ついで水を加えて全量 $10.0 \mathrm{~m} l$ とする. 別に チオ尿素を除いて同じように処理して得た 3,4,5,6-T. Cl. Fl. $\mathrm{Hg}_{4}$ 液とともに $20 \sim 35^{\circ} \mathrm{C}$ で 30 分間静置した のち，水銀ランプを光源として $365 \mathrm{~nm}$ の励起波長を用 いて，3, 4, 5, 6-T.Cl.Fl. $\mathrm{Hg}_{4}$ 液と 3, 4, 5, 6-T.Cl.Fl. $\mathrm{Hg}_{4}$-チオ尿素溶液とのけい光強度 の差を $555 \mathrm{~nm}$ で測 定する. ついであらかじめ作成して得た $0 \sim 19.5 \mu \mathrm{g} / 10$ $\mathrm{m} l$ チオ尿素の検量線よりチ才尿素濃度を求める.

\section{2 塩化セチルピリジニウム}

$1.0 \mu \mathrm{g}$ 以下の CPC を含む溶液に $1.0 \% \mathrm{PVP}$ 液 1.0 $\mathrm{m} l$, 緩衝液 ( $\mathrm{pH} 6.95) 2.0 \mathrm{~m} l$ および $5.0 \times 10^{-4} M 3$, 4, 5, 6-T.Cl. Fl. $\mathrm{Hg}_{4}$ 液 $0.25 \mathrm{ml}$ を加え, ついで水を加 えて全量 $10.0 \mathrm{~m} l$ とする. 別に $\mathrm{CPC}$ の夕除いて同じ ように処理して得た $3,4,5,6-\mathrm{T} . \mathrm{Cl} . \mathrm{Fl} . \mathrm{Hg}_{4}$ 液とともに $20 \sim 35^{\circ} \mathrm{C}$ で約 10 分間静置する. ついで水銀ランプを 光源とする $365 \mathrm{~nm}$ の励起波長を用いて $3,4,5,6-\mathrm{T}$. Cl.Fl. $\mathrm{Hg}_{4}$ 液と $3,4,5,6$-T.Cl.Fl. $\mathrm{Hg}_{4}-\mathrm{CPC}$ 液との $555 \mathrm{~nm}$ でのけい光強度の差を測定し, あらかじめ作成 して得た $0.15 \sim 1.0 \mu \mathrm{g} / 10 \mathrm{ml}$ CPC の検量線より CPC 濃度を求める.

\section{4 定量操作の検誴}

\subsection{F1 誘導体の水銀化合物の合成}

2', 7'-D.Cl.Fl の水銀化反応 ${ }^{8)}$ を参考として F1，2'，
7'-D.Cl. Fl，2'，4'-D.Cl.Fl あるいは 3, 4, 5, 6-T.Cl.Fl のそれぞれ $2.0 \mathrm{~g}$ を $5 \%$ 水酸化ナトリウム液 $5.0 \mathrm{ml}$ に 溶解し，不溶物質を沪別したのち，酢酸第二水銀 $7.0 \mathrm{~g}$ の酢酸溶液を加える. ついで $30 \%$ 酢酸および $1 N$ 水酸 化ナトリウムを用いて液性を $\mathrm{pH}$ 5〜6に調整後, 水を 加えて全量をほぼ $250 \mathrm{ml}$ とし，95〜 $100^{\circ} \mathrm{C}$ で約 10 時間 加熱かき混ぜた. 反応終了後，30\% 酢酸を加えて得た 水銀化合物を $5 \%$ 水酸化ナトリウムおよび $30 \%$ 酢酸 を用いて再沈殿処理し，じゅうぶえ水洗したのち風乾す る. これら Fl 誘導体の水銀化合物は PPC 展開（展開 溶媒に $10 \%$ フェノール: $1 N$ 水酸化ナトリウム: 水= $1: 2: 7$, 東洋沪紙 No. 50 , 原点 $5.0 \mathrm{~cm}$ を用いる上 昇法）の結果，および 水銀ならびに塩素の 定量結果よ り，それぞれ $\mathrm{Fl}\left(\mathrm{HgOCOCH}_{3}\right)_{4}, 2^{\prime}, 4^{\prime}$-D.Cl.Fl(HgO$\left.\mathrm{COCH}_{3}\right)_{2}, 2$ ', 7'-D.Cl. Fl $\left(\mathrm{HgOCOCH}_{3}\right)_{2}$ および 3, 4, 5,6-T.Cl.Fl $\left(\mathrm{HgOCOCH}_{3}\right)_{4}$ と推定される.

\section{2 チオ尿素誘導体と F1 誘導体の 水銀化合物 との} 反応

Fl 誘導体の水銀化合物, 特に $3,4,5,6$-T.Cl.Fl. $\mathrm{Hg}_{4}$ 液はチオ尿素, ジトリルチオ尿素, ジフェニルチオ尿 素, フェニルチオ尿素, チオアセトアミドあるいはチオ セミカルバジドなどのチオカルボニル化合物と反応して 赤色呈色体を生成し， $\mathrm{Fl} . \mathrm{Hg}_{4}$ を用いた場合に比べて呈 色が安定，鋭敏で，Grote 試液を用いた場合6)7にに比べ， ほぼ数倍の感度を示した.なお, Table II にこれら Fl 誘導体の水銀化合物とチオ永素誘導体との試験管内での 検出限界值とその呈色を示した. 以下，試薬の濃度は最 終濃度で表示するものとし， pH 8.9 の液性調整には Sörensen のほう砂-水酸化ナトリウム液（pH 8.9）2.0 $\mathrm{ml}$ を, $\mathrm{pH} 6.95$ の液性調整には同じくほう砂-掹酸液 (pH 6.95) $2.0 \mathrm{ml}$ を加えて, 最終容積を $10.0 \mathrm{ml}$ と した.

\section{3 けい光スペクトル}

最終濃度 $5.0 \times 10^{-5} M \mathrm{Fl}$ 誘導体の水銀化合物と, そ

Table I Properties of Fl. derivatives of $\mathrm{Hg}$ compounds

\begin{tabular}{|c|c|c|c|c|c|c|c|c|}
\hline \multirow{3}{*}{$\begin{array}{l}\text { Fl. deriv. } \mathrm{Hg} \\
\text { compounds }\end{array}$} & \multirow{2}{*}{\multicolumn{2}{|c|}{ Color of }} & \multicolumn{2}{|c|}{ P.P.C. } & \multicolumn{4}{|c|}{ Analysis of } \\
\hline & \multirow[b]{2}{*}{ Appearence } & & 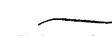 & - & \multicolumn{2}{|c|}{$\mathrm{Hg} \%$} & \multicolumn{2}{|c|}{$\mathrm{Cl} \%$} \\
\hline & & $\begin{array}{c}\mathrm{NaOH} \\
\text { soln. }\end{array}$ & $\begin{array}{l}\text { Color of } \\
\text { spot }\end{array}$ & $R_{f}$ & Calcd. & Found & Calcd. & Found \\
\hline Fl. $\mathrm{Hg}_{4}$ & rd Or & y Or & p Rd & 0.09 & 58.72 & 57.49 & - & 一 \\
\hline $2^{\prime}, 4^{\prime}$-D.Cl.Fl. $\mathrm{Hg}_{2}$ & $\mathrm{Rd}$ & Or & rd $P$ & 0.11 & 43.83 & 43.51 & 7.73 & 7.42 \\
\hline $2^{\prime}, 7^{\prime}-\mathrm{D} . \mathrm{Cl} \cdot \mathrm{Fl} \cdot \mathrm{Hg}_{2}$ & $\mathrm{Rd}$ & $\mathrm{Or}$ & p Or & 0.15 & 43.83 & 43.97 & 7.73 & 7.77 \\
\hline $3,4,5,6$-T.Cl.Fl.Hg & $\mathrm{Rd}$ & $\mathrm{rd} \mathrm{Or}$ & $\mathrm{P}$ & 0.12 & 53.19 & 54.00 & 9.41 & 9.58 \\
\hline $\begin{array}{l}\text { Developing solvent : } 10 \% \\
\text { P : Pink }\end{array}$ & henol 1: & $\mathrm{NaOH}$ & 7 & dish; & lowish; & inkish; & range; & : red; \\
\hline
\end{tabular}


Table II Detection limits of thiourea derivatives by $\mathrm{Fl}$. derivatives $\mathrm{Hg}$ compounds

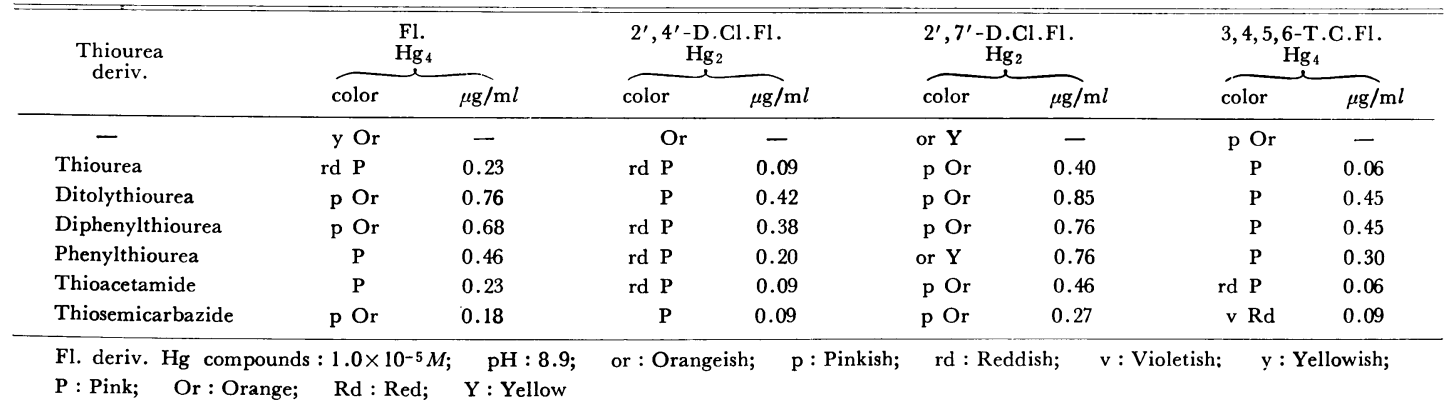

のチオ尿素溶液, あるいは CPG 溶液とのけい光強度の 差を測定したところ，Table III に見られるように，い ずれも 3, 4, 5,6-T.Cl.Fl. $\mathrm{Hg}_{4}$ 液を用いたとき, 最もけ い光強度の差が大で, その呈色体も比較的安定である. したがって以下チオ尿素あるいは CPC のけい光光度定 量に 3, 4, 5,6-T.Cl. Fl. $\mathrm{Hg}_{4}$ を用いることとした.

Table III Difference of fluorescence intensity of Fl. derivatives $\mathrm{Hg}$ compounds and it's thiourea or it's CPG solution

\begin{tabular}{lccc}
\hline $\begin{array}{c}\text { Fl. deriv. } \\
\mathrm{Hg} \text { compounds }\end{array}$ & $\begin{array}{c}\text { Emission, } \\
\text { wavelength } \\
\text { (nm) }\end{array}$ & $\begin{array}{c}\text { Thiourea } \\
\text { (pH 8.9) }\end{array}$ & $\begin{array}{c}\mathrm{CPC} \\
(\mathrm{pH} \mathrm{6.9)}\end{array}$ \\
\hline Fl. $\mathrm{Hg}_{4}$ & 540 & 21.2 & 26.3 \\
2' $^{\prime}, 4^{\prime}$-D.Cl.Fl. $\mathrm{Hg}_{2}$ & 540 & 24.7 & 16.8 \\
2' $^{\prime}, 7^{\prime}$-D.Cl.Fl. $\mathrm{Hg}_{2}$ & 540 & 18.5 & 38.8 \\
3, 4, 5,6-T.Cl.Fl. $\mathrm{Hg}_{4}$ & 555 & 30.4 & 60.4 \\
\hline
\end{tabular}

Fl. deriv. $\mathrm{Hg}$ compounds: $5.0 \times 10^{-5} \mathrm{M}$; $\mathrm{CPC}$, or thiourea taken : $1.25 \times 10^{-5} M$; Excitation wavelength : $365 \mathrm{~nm}$

Fig. 1 に pH 8.9 に打け $365 \mathrm{~nm}$ を励起波長とす る $5.0 \times 10^{-5} M$ の $\mathrm{Fl}$ 誘導体の 水銀化合物の 溶液のけ い光スペクトルを示した.

\section{4 液性の影響}

$\mathrm{pH}$ の変化による $3,4,5,6-\mathrm{T} . \mathrm{Cl} . \mathrm{Fl} . \mathrm{Hg}_{4}$ 液と 3,4 , 5, 6-T.Cl.Fl. $\mathrm{Hg}_{4}$-チ才尿素，あるいは GPG 溶液との けい光強度の差は，それぞれ Sörensen の $0.05 M$ ほう 砂 $-0.1 N$ 水酸化ナトリウム液 $2.0 \mathrm{ml}$ を用いる $\mathrm{pH} 8.5$ $\sim 9.4$, および $0.05 M$ ほう砂 $-0.1 N$ 塩酸液 $2.0 \mathrm{ml}$ を 用いる $\mathrm{pH}$ 6.7〜7.2 においてほぼ一定值が得られた.

\section{5 けい光の安定性}

3, 4, 5, 6-T.Cl.Fl.Hg４液とそのチ才尿素液，あるい は CPG 溶液についてけい光の安定性を求めたところ,

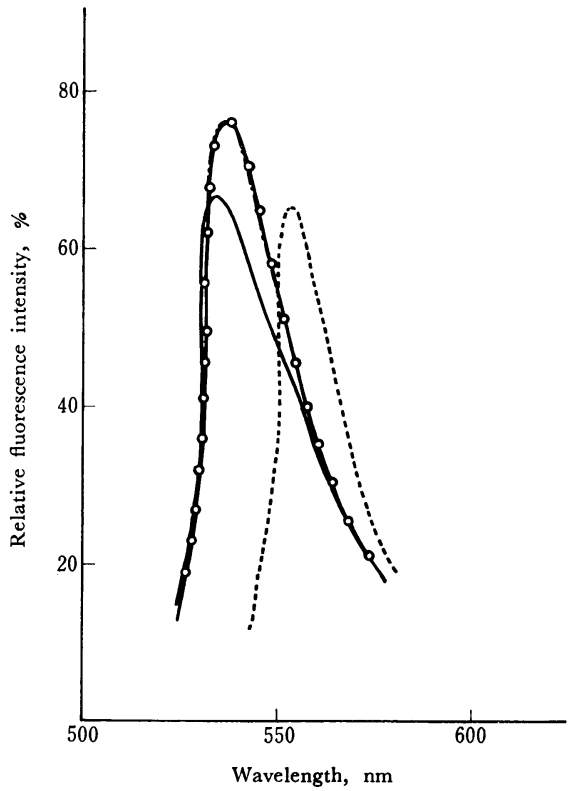

Fig. 1 Emission spectra of $\mathrm{Fl} . \mathrm{Hg}_{4}, 2^{\prime}, 4^{\prime}-\mathrm{D} . \mathrm{Cl}$. Fl. $\mathrm{Hg}_{2}, 2^{\prime}, 7^{\prime}-\mathrm{D} . \mathrm{Cl} . \mathrm{Fl} . \mathrm{Hg}_{2}$ and $3,4,5,6-$ T.Cl. Fl. $\mathrm{Hg}_{4}$ soln. at $\mathrm{pH} 8.9$

Fl. $\mathrm{Hg}_{4}$, Cl.Fl. $\mathrm{Hg}: 5.0 \times 10^{-5} \mathrm{M}$; Excitation wavelength : $365 \mathrm{~nm} ;-\mathrm{Fl} . \mathrm{Hg}_{4} ;---2^{\prime}, 4^{\prime}-\mathrm{D} . \mathrm{Cl}$ Fl. $\mathrm{Hg}_{2} ; \quad-\mathrm{O}-2^{\prime}, 7^{\prime}-$ D.Cl.Fl. $\mathrm{Hg}_{2} ;---3,4,5$, 6-T.Gl.Fl. $\mathrm{Hg}_{4}$

$20 \sim 35^{\circ} \mathrm{C}$ で 30 分間，あるいは 10 分間静置するとき, ほぼ一定のけい光強度の差が得られた.

なお，3, 4, 5, 6-T.Cl.Fl. $\mathrm{Hg}_{4}$-CPG 液は比較的不安定 であるが， $1.0 \%$ PVP 液 $1.0 \mathrm{ml}$ を添加することによ り安定化することができ， $60^{\circ} \mathrm{C}$ 以下であれぼほとんど 温度の影響をうけない.

\section{$4.63,4,5,6$-T.C1.F1.Hg 4 濃度の影響}

$1.25 \times 10^{-5} M$ チオ尿素, あるいは $2.5 \times 10^{-5} M \mathrm{CPC}$ 


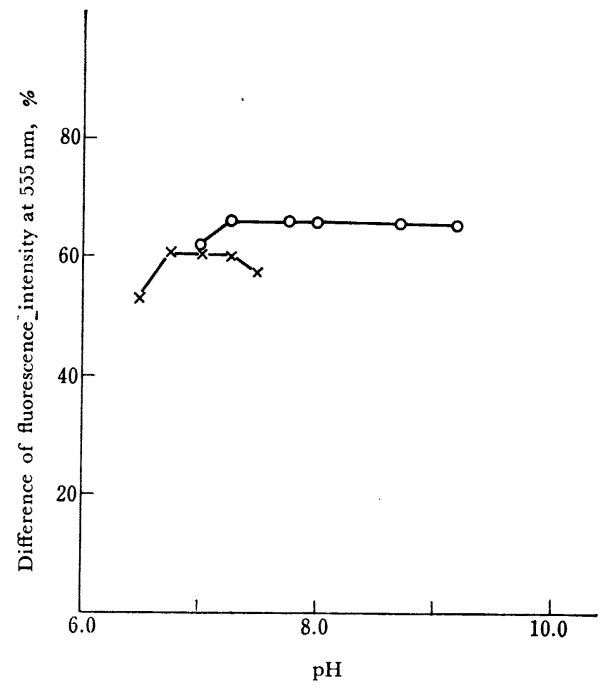

Fig. 2 Effect of $\mathrm{pH}$

$-\mathrm{O}-3,4,5,6$-T.Cl.Fl. $\mathrm{Hg}_{4}$-thiourea, 3, 4,5,6-T.Cl. Fl. $\mathrm{Hg}_{4}: 1.0 \times 10^{-4} M$, thiourea : $1.25 \times 10^{-5} M ;-\times-$ 3, 4, 5,6-T.Cl.Fl. $\mathrm{Hg}_{4}$-CPC, $3,4,5,6$-T.Cl.Fl. $\mathrm{Hg}_{4}$ : $2.5 \times 10^{-5} \mathrm{M}, \mathrm{CPC}: 1.25 \times 10^{-5} \mathrm{M}, \mathrm{PVP}: 1.0 \mathrm{~m} l ; \mathrm{Ex}-$ citation wavelength : $365 \mathrm{~nm}$

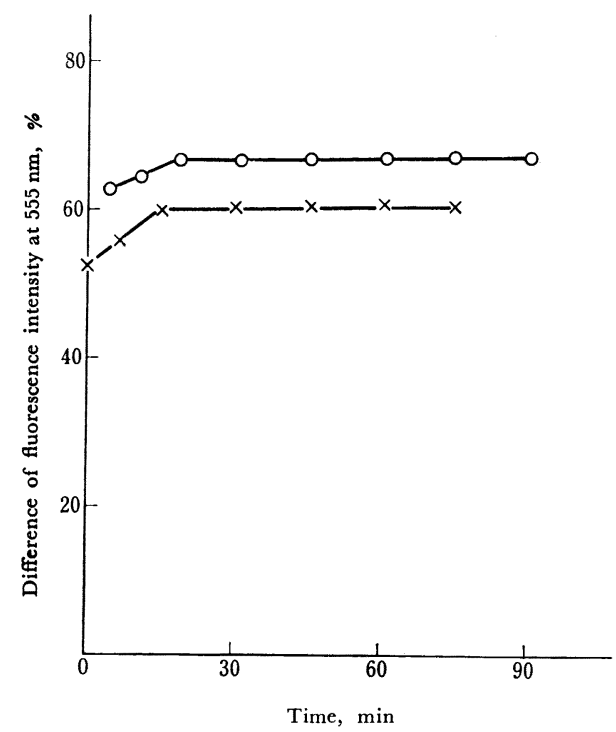

Fig. 3 Stability of $3,4,5,6-\mathrm{T} . \mathrm{Cl} . \mathrm{Fl} . \mathrm{Hg}_{4}$-thiourea and $3,4,5,6-$ T.Cl.Fl. $\mathrm{Hg}_{4}-\mathrm{CPC}$ soln.

-O- 3,4,5,6-T.Gl.Fl. $\mathrm{Hg}_{4}$-thiourea, 3,4,5,6-T.Cl. $\mathrm{Fl} . \mathrm{Hg}_{4}: 1.0 \times 10^{-4} \mathrm{M}$, thiourea : $1.0 \times 10^{-5} \mathrm{M}, \mathrm{pH}$ : $8.9 ;-\times-3,4,5,6$-T.Cl.Fl. $\mathrm{Hg}_{4}$-CPC, 3, 4, 5, 6-T. Cl. Fl. $\mathrm{Hg}_{4}: 2.5 \times 10^{-5} \mathrm{M}, \quad \mathrm{CPC}: 1.25 \times 10^{-5} \mathrm{M}, \quad \mathrm{PVP}:$ $1.0 \mathrm{ml}, \mathrm{pH}: 6.95 ; \quad$ Excitation wavelength $: 365 \mathrm{~nm}$

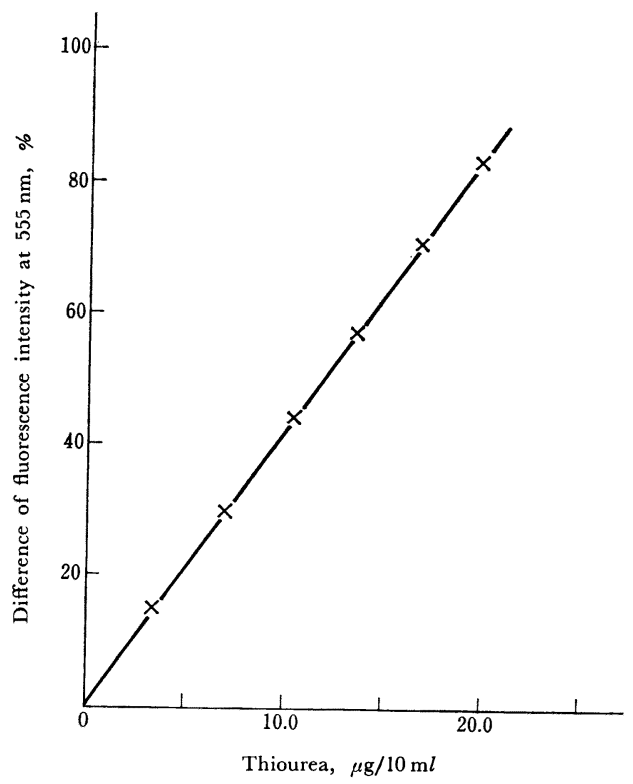

Fig. 4 Calibration curve for thiourea

3, 4, 5,6-T.Cl. Fl. $\mathrm{Hg}_{4}: 1.0 \times 10^{-4} M ; \mathrm{pH}: 8.9$; Excitation wavelength $: 365 \mathrm{~nm}$

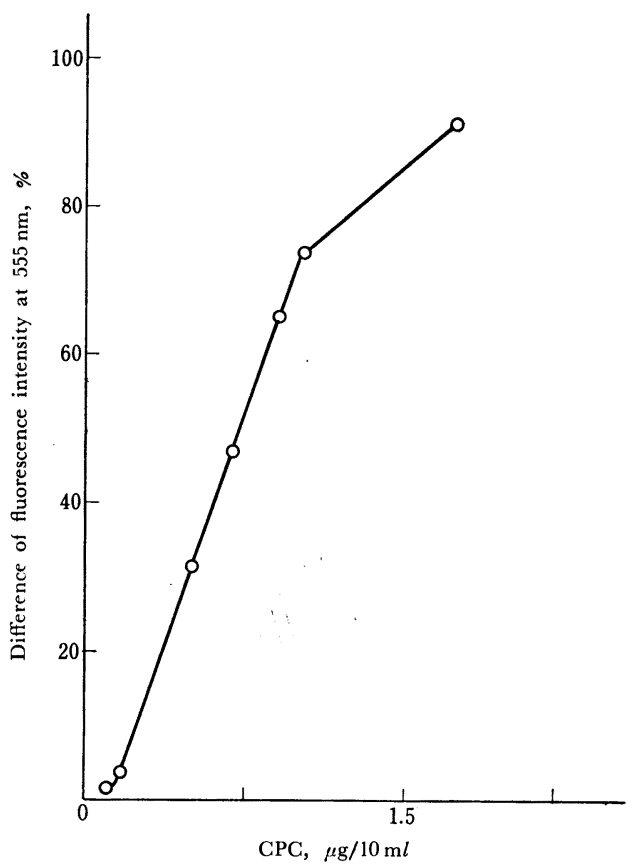

Fig. 5 Calibration curve for CPG

3, 4, 5,6-T.Cl.Fl. $\mathrm{Hg}_{4}: 1.25 \times 10^{-5} \mathrm{M} ; \quad \mathrm{PVP}: 1.0 \mathrm{ml}$; $\mathrm{pH}: 6.95 ;$ Excitation wavelength $: 365 \mathrm{~nm}$ 
に対する 3, 4, 5, 6-T.Cl.Fl. $\mathrm{Hg}_{4}$ 液濃度の影響について 検討したところ，チオ尿素に対して 3,4,5,6-T.Cl Fl.

$\mathrm{Hg}_{4}$ を $8.75 \times 10^{-5} M$ 以上，また $\mathrm{CPC}$ に対して 1.25 $\times 10^{-5} M$ 以上を添加するとき, けい光強度の差の測定に 際しじゅうぶんな值を示した.したがって以下，チ才尿 素の定量に $1.0 \times 10^{-4} M$ の $3,4,5,6-\mathrm{T} . \mathrm{Cl} . \mathrm{Fl} . \mathrm{Hg}_{4}$ 液 を，また CPC の定量に $1.25 \times 10^{-5} M$ の 3,4,5,6-T. Cl.Fl. $\mathrm{Hg}_{4}$ 液を用いることとした.

\section{7 検量線の作成}

3 の定量操作に従ってチ才尿素，ならびに CPC の検 量線を作成したところ，Fig. 4 および Fig. 5 に見られ るように 0〜 $19.5 \mu \mathrm{g} / 10 \mathrm{ml}$ チ才尿素，ならびに $0.15 〜$ $1.0 \mu \mathrm{g} / 10 \mathrm{~m} l \mathrm{CPC}$ の濃度範囲においてほぼ直線性を示 した.

\section{8 共存物質の影響}

3, 4, 5, 6-T.Cl.Fl. $\mathrm{Hg}_{4}$ を用いるチ才尿素あるいは CPC のけい光光度定量法においてチオカルボニル化合 物, $\mathrm{NH}_{4}{ }^{+}, \mathrm{S}_{2} \mathrm{O}_{3}{ }^{2-}, \mathrm{S}^{2-}$ などの共存, ならびに過剰の 金属イオンの共存は正の誤差を示して妨害する.なお， $5.0 \times 10^{-4} M$ 以下の EDTA, IDA あるいは $1,10-フ ェ$ ナントロリンなどの共存はほとんどチオ尿素, CPG の けい光光度定量を妨害しないので金属イオンのマスク剂 として用いることができる.

Table IV Effects of foreign ions

\begin{tabular}{llccc}
\hline $\begin{array}{c}\text { Foreign } \\
\text { ions }\end{array}$ & Added as & $\begin{array}{c}\text { Added } \\
\left(\times 10^{-5} \mathrm{M}\right)\end{array}$ & $\begin{array}{c}\text { Difference of fluorescence } \\
\text { intensity }\end{array}$ & $\begin{array}{c}(\%) \\
\text { Thiourea }\end{array}$ \\
\hline- & - & - & 32.0 & 57.6 \\
$\mathrm{Th}(\mathrm{IV})$ & nitrate & 1.25 & 65.5 & 81.6 \\
$\mathrm{Al}(\mathrm{III})$ & nitrate & 1.25 & 77.5 & 96.8 \\
$\mathrm{Cd}(\mathrm{II})$ & nitrate & 1.25 & 58.3 & 76.9 \\
$\mathrm{Bi}(\mathrm{III})$ & nitrate & 1.25 & 60.5 & 75.1 \\
$\mathrm{Ge}(\mathrm{IV})$ & chloride & 1.25 & 54.2 & 50.5 \\
$\mathrm{MoO}_{4}{ }^{2-}$ & sodium & 1.25 & 42.6 & 64.6 \\
$\mathrm{VO}_{3}{ }^{-}$ & ammonium & 1.25 & 53.9 & 71.7 \\
EDTA & sodium & 5.0 & 32.5 & 57.8 \\
$\mathrm{IDA}$ & sodium & 5.0 & 32.4 & 57.9 \\
phen & & 5.0 & 32.5 & 57.8 \\
\hline
\end{tabular}

Thiourea-Thiourea taken : $6.5 \mu \mathrm{g}, 3,4,5,6-\mathrm{T} . \mathrm{Cl} . \mathrm{Fl} . \mathrm{Hg}_{4}: 1.0$ $\times 10^{-4} M, \mathrm{pH}: 8.9 ; \quad$ GPC-CPC taken $: 0.8 \mu \mathrm{g}, 3,4,5,6-\mathrm{T} . \mathrm{Cl}$. Fl. $\mathrm{Hg}_{4}: 1.25 \times 10^{-5} M, \mathrm{pH}: 6.95$

\section{5 結果および考察}

3, 4, 5, 6-T.Cl.Fl. $\mathrm{Hg}_{4}$ を用いるチオ尿素, あるいは CPC のけい光光度定量法はチオ尿素に混在する 尿素の
影響をほとんどうけず，その呈色も鮮明かつ比較的安定 で定量感度も高いなどの利点を有する．また過剩に共存 する金属イオンの影響は EDTA，IDA などの錯化剂の 添加でほとえどマスクすることができる.なお，3,4,5, 6-T.Cl.Fl. $\mathrm{Hg}_{4}$ を用いた GPG のけい光光度定量法は さきの CPC の吸光光度定量法9) に比べて, 約 $20 \sim 30$ 倍の定量感度を有する迅速簡便な定量法である.

終わりに，本研究に対しご指導賜わった京都大学薬学 部宇野豊三教授に深謝します。 また実験の一部に協力さ れた本学小山 良君に感謝します.

$(1972$ 年 4 月，1973 年 4 月，日本薬 $)$ 学会第 92 年, 93年 会において発表)

\section{交献}

1) M. Wronski : Chem. anal., 14, 29 (1968); Anal. Abstr., 18, 4250 (1970).

2) V. S. Yanashova : Zavodsk. Lab., 30, 23 (1964); Anal. Abstr., 12, 1688 (1965).

3) M. Wronski : Chem. anal., 13, 737 (1968).

4) C. Geroge, H. Marhta, F. Henry : Talanta, 17, 273 (1970).

5）森 逸男：薬誌，85，481(1965).

6) 赤塚政美, 天本宏太郎，吉永節洋：本誌，19, 1427 (1970).

7) L. G. Chesler : J. Bio. Chem., 152, 571 (1944).

8）大野武男，森 逸男：岐阜薬大，17，83 (1967).

9) 森逸男, 小山 良: 日本薬学会第 92 年会講演 要旨, IV, p. 102 (1972).

$$
\text { š }
$$

Fluorophotometric determination of thiourea and cetylpyridinium chloride with 3,4,5,6-tetrachlorofluorescein mercury compound. Itsuo MORI (Osaka College of Pharmacy, 2-10-65, Kawai, Matsubara-shi, Osaka)

A highly sensitive and brief fluorophotometric determination for minute amounts of thiourea and cetylpyridinium chloride(CPG) was carried out using $2^{\prime}, 4^{\prime}, 5^{\prime}, 7^{\prime}$-tetrakis (acetoxymercuri) fluorescein $\left(\mathrm{Fl} . \mathrm{Hg}_{4}\right)$, $5^{\prime}, 7^{\prime}$-bis (acetoxymercuri)-2',-4' -dichlorofluorescein $\left(2^{\prime}\right.$,$4^{\prime}$-D.Cl.Fl. $\mathrm{Hg}_{2}$ ), 4', $5^{\prime}$-bis (acetoxymercuri) $-2^{\prime}, 7^{\prime}$-dichlorofluorescein $\left(2^{\prime}, 7^{\prime}\right.$-D.Cl.Fl. $\left.\mathrm{Hg}_{2}\right)$ and $2^{\prime}, 4^{\prime}, 5^{\prime}, 7^{\prime}$-tetrakis (acetoxymercuri) -3, 4, 5, 6-tetrachlorofluorescein (3, 4, 5,6-T.Cl.Fl. $\mathrm{Hg}_{4}$ ) as the reagents. Among these mercurichlorofluorescein compounds, 3, 4, 5, 6-T.Cl.Fl. $\mathrm{Hg}_{4}$ produced a very stable and red colored formation with thiourea or CPG solution and showed a marked decrease in its fluorescence intensity, which was applied to the fluorophotometric determination of thiourea and CPC. The fluorescence intensity of 3,4,5,6T.Cl.Fl. $\mathrm{Hg}_{4}$-thiourea solution was constant over the $\mathrm{pH}$ range of 8.5 to 9.4 adjusting with $\mathrm{Na}_{2} \mathrm{~B}_{4} \mathrm{O}_{7}-\mathrm{NaOH}$ solution, and the fluorescence intensity of $3,4,5,6-$ T.Cl.Fl. $\mathrm{Hg}_{4}-\mathrm{CPC}$ solution was constant over the $\mathrm{pH}$ range of 6.7 to 7.2 adjusting with $\mathrm{Na}_{2} \mathrm{~B}_{4} \mathrm{O}_{7}-\mathrm{HCl}$ buffer solution. The maximum emission wavelength of difference in fluorescence intensity between $3,4,5,6$ T.Cl.Fl. $\mathrm{Hg}_{4}$ solution and $3,4,5,6-$ T.Cl.Fl. $\mathrm{Hg}_{4}-$ 
thiourea or $3,4,5,6$-T.Cl.Fl. $\mathrm{Hg}_{4}-\mathrm{CPC}$ solution were about $555 \mathrm{~nm}$. The calibration curves were linear in the range of 0 to $19.5 \mu \mathrm{g} / 10 \mathrm{ml}$ thiourea and 0.15 to $1.0 \mu \mathrm{g} / 10 \mathrm{ml}$ CPG. The recommended fluorophotometric analytical procedures for thiourea and CPG are as follows:

Thiourea-A sample solution containing less than $19.5 \mu \mathrm{g}$ of thiourea is taken in a $10.0 \mathrm{ml}$ measuring flask to which $2.0 \mathrm{ml}$ of Sörensen buffer solution $(\mathrm{pH} 8.9)$ and $2.0 \mathrm{ml}$ of $5.0 \times 10^{-4} M 3,4,5,6$-T.Cl.Fl. $\mathrm{Hg}_{4}$ solution are added. The whole is made up to mark with distilled water, and the solution is kept at $20 \sim 35^{\circ} \mathrm{C}$ for 30 minutes, then the fluorescence intensities of 3,4 , 5, 6-T.Cl.Fl.Hg ${ }_{4}$ solution and 3, 4, 5, 6-T.Cl.Fl. $\mathrm{Hg}_{4}$ thiourea solution are measured at $555 \mathrm{~nm}$.
GPG - A sample solution containing less than 1.0 $\mu \mathrm{g}$ of CPC is taken in a $10.0 \mathrm{ml}$ measuring flask. 2.0 $\mathrm{m} l$ of Sörensen buffer solution ( $\mathrm{pH} 6.95), 1.0 \mathrm{ml}$ of $1.0 \%$ polyvinylpyrolidone(PVP) solution and $0.25 \mathrm{ml}$ of $5.0 \times 10^{-4} M 3,4,5,6$-T.Cl.Fl. $\mathrm{Hg}_{4}$ solution are added. The whole is made up to the mark with distilled water, and the solution is kept at $20 \sim 35^{\circ} \mathrm{G}$ for 10 minutes, then the fluorescence intensities of $3,4,5,6$ T.Cl.Fl. $\mathrm{Hg}_{4}$ solution and $3,4,5,6$-T.Cl.Fl. $\mathrm{Hg}_{4}-\mathrm{CPC}$ solution are measured at $555 \mathrm{~nm}$.

The effects of foreign ions on the fluorescence intensity of the colored formation were examined and shown in Table V. The reaction is quite sensitive, and the procedure does not require a long time.

(Received Nov. 10, 1973)

\title{
核磁気共鳴法によるクレゾール，トルイル酸および トルイジン 3 異性体の定量
}

\author{
安田 誠二, 垣山 仁夫*
}

(1973 年 11 月 27 日受理)

\begin{abstract}
クレゾール，トルイル酸およびトルイジンのオルト，メタ，パラ異性体の定量を核磁気共鳴法によっ て行なった.クレゾール $0.5 \mathrm{~g} / \mathrm{ml}$ の $2 N$ 水酸化ナトリウム溶液，トルイル酸 $0.5 \mathrm{~g} / \mathrm{m} l$ の $4 N$ 水酸 化ナトリウム溶液, およびトルイジン $0.5 \mathrm{~g} / \mathrm{ml}$ の $4 N$ 塩酸溶液について, 各異性体のメチルピーク を測定すると，ピークは鋭い単一線となり，低磁場側からオルト，メタ，パラの順に分離した．各メチ ルビークの分離は，クレゾールでオルトーメタ間 $0.06 \mathrm{ppm}$ ，メターパラ間 $0.05 \mathrm{ppm}$ ，トルイル酸でオ

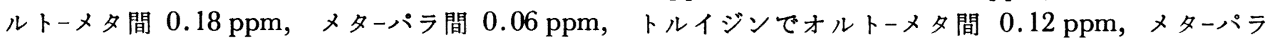
間 $0.04 \mathrm{ppm}$ であった．分離したメチルビークの高さ比を測定することによって，3\%から 80\%の間 の各異性体を $\pm 1.3 \%$ 以内の誤差で定量することができた.
\end{abstract}

\section{1 緒㝘}

クレゾール異性体の分離定量法としては，従来ガスク ロマトグラフ法1) や紫外2) および赤外線吸収法3) があ り，トルイジンについては，ガスクロマトグラフ法4)や ペーパークロマトグラフ法5)がある．また，トルイル酸 の異性体の分離定量法についてはほとえど報告がない。 核磁気共鳴法による定量は，これらの定量法に比べて操 作が簡単で，直接非破壊に測定できるため，各方面への 応用が検討されている6) 13).

Mathias 58)9) は，ジニトロおよびジアミノトルエン の各異性体のメチルピークが重クロロホルム溶媒中で,

\footnotetext{
* 九州工業技術試験所 : 佐賀県鳥栖市宿町
}

Gehring ら11)12) は，ジおよびトリニトロトルェンの異 性体のメチルピークが重アセトン溶媒中で，それぞれ分 離することから各異性体の定量分析を行なっている. Fujiwara ら6) は，xチルナフタレンの $\alpha$ および $\beta$ 異性 体のメチルピークが四塩化炭素溶媒を用いて測定すると 分離することから，2 異性体の定量を行なっている.

$$
\text { クレゾール, トルイル酸およびトルイジンのオルト, }
$$
メタ，パラ異性体のメチルピークは，通常の溶媒中で測 定すると 1 本の鋭いピークとなるが，単一溶媒中での各 メチルピークの化学シフト差はきわめて小さい. 和井内 ら7) は, クレゾール 異性体のメチルピークが水-メタノ 一ル混合溶媒中で分離することから，各異性体の定量を 行なっている. 